\title{
PRETERM LABOUR:
}

TO DETERMINE THE FREQUENCY OF FACTORS LEADING TO PRETERM LABOUR,

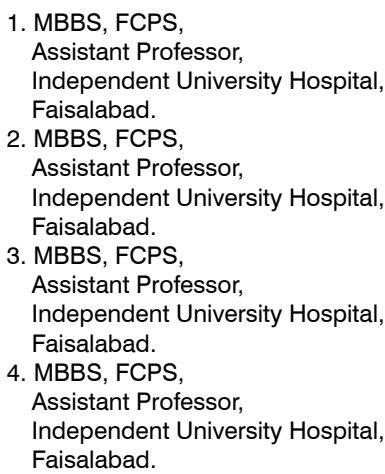

Correspondence Address:

Dr. Tasneem Azher

Assistant Professor,

Independent University Hospital,

Faisalabad.

gynaeiuh@gmail.com

Article received on: 24/05/2017

Accepted for publication: 15/07/2017

Received after proof reading:

08/09/2017
Tasneem Azher ${ }^{1}$, Iram Aslam², Saadia Bano ${ }^{3}$, Uzma Shahzad ${ }^{4}$

ABSTRACT... Objectives: (1) to find out of aetiological factors of preterm labour. (2) To make a proposed remedy for prevention of preterm lobour. Material and Methods: This study was carried out at Independent University Hospital. This is located at richly populated area of Faisalabad, providing health care facilities to poor socioeconomic group. The patient who fit into inclusion criteria was included in study and a well designed Proforma was used to collect the sample. Duration of study: One year study from 1 May, 2014 to 30 April, 2015. Study design: It is a descriptive study. Sampling technique: A purposive random sample technique was used to collect the sample. Sample size: A total of 80 cases ware collected who were admitted through antenatal outdoor and emergency of IUH. Inclusion Criteria: All patients with diagnosed preterm labour who had attended outdoor or emergency of Independent University Hospital were included in study. Exclusion Criteria: (1) Patients with latrogenic preterm induction of labour due to maternal factors like patients on chemo therapy or any debilitating illness causing threat to maternal life. (2) Patients with congenitally abnormal foetus \& intra uterine death of fetus. Results: A total of 80 cases with preterm labour were included in study at Independent University Hospital. In current study 30 (37.5\%) patients had age between 18 25 years, $30(37.5 \%)$ patients had age between $26-35$ years and rest of the $20(25 \%)$ patients had age $>35$ years. Among 80 patients $25(31.3 \%)$ patients had parity b/w 1-3 while $28(35 \%)$ patients had parity b/w $4-5$ and rest of the $27(33.8 \%)$ had parity $>5$. More patients i.e 50 (62.5\%) patients were admitted through emergency while 30 (37.5\%) patients were admitted through Out Patient Department (OPD). 37 (46.3\%) patients had Spontaneous vaginal delivery and $43(53.8 \%)$ patients underwent lower segment cesarean section. In our study, the most common risk factor associated with preterm labour was bacterial vaginosis $20(25 \%)$ patients had bacterial vaginosis. $10(12.5 \%)$ patients had chorioamniotis. Previous history of preterm birth was present in $10(12.5 \%)$ patients. History of Preterm Premature ruptures of membranes in $8(10 \%)$ patients. 11(13.5\%) patients has history of previous C-section and impending scar dehiscence. History of anti partum hemorrhage and pregnancy induce in hypertension was present in $5(6.5 \%)$ patients. FGR with oligohydramnios was present in $6(7.5 \%)$ patients. 3 ((3.75\%) patients presented with preterm breech

Key words: $\quad$ Preterm Labour, Preterm Premature Ruptures of Membranes (PPROM) Foetal Growth Restriction (FGR).

Article Citation: Azhar T, Aslam I, Bano S, Shahzad U. Preterm labour: to determine the frequency of factors leading to preterm labour. Professional Med $\mathrm{J}$ 2017;24(9):1376-1379. DOI: 10.17957/TPMJ/17.3776

\section{INTRODUCTION}

A normal pregnancy lasts 37 to 42 wks accounting from the $1^{\text {st }}$ day of last menstrual of period. A pregnancy that continuous beyond 37 wks is called a "term" pregnancy. Preterm labour is defined as labour that begins before 37 wks of pregnancy. The incidence of preterm labour is five to ten percent in developed countries. In the United States of America, the incidence has risen about nine percent to twelve percent in the previous two decades. Premature labour is the only worth noticeable risk for perinatal morbidity and loss. ${ }^{1}$ In 2011, 9 percent of all births were prior to 37 weeks. It is difficult to predict who will develop preterm labour. There are certain obstetrical conditions and other factors which may lead to preterm labour. However most preterm births occur in women who have no known risk factors. 
To scrutinize patients for premature labour is always problematic. To categorize the patients into low risk and into high risk is not based on hypothetical approach but definitely some demographic variables like age, nulliparity, thin long females, low social class has some relation with premature delivery. ${ }^{3}$ The strongest risks for birth prior to 37 weeks are a previous history of preterm birth. The chance of premature delivery after 1 premature birth is 15 percent and after 2 is 41 percent respectively. ${ }^{3}$ The other risk factors of preterm labour are poor nutrition and malnutrition, multiple pregnancy, maternal age, unfavorable living situations, and smoking etc. the purpose of current study is to determine the frequency of factors leading to preterm labour and to propose remedy to prevent preterm labour.

\section{RESULTS}

80 cases were with preterm labour were included in study at Independent University Hospital where annual attendance of patients through outdoor and indoor is $>6000 / y$ r. All patients were evaluated with detailed history and clinical examination. All necessary investigations mentioned in proforma have done to evaluate the risk factors and possible aetiology.

\begin{tabular}{|c|c|c|}
\hline \multicolumn{3}{|c|}{ Distribution of patients according to age of mother } \\
\hline Age & No. of Patients & $\%$ age \\
\hline $18-25$ & 30 & $37.5 \%$ \\
\hline $26-35$ & 30 & $37.5 \%$ \\
\hline$>35$ & 20 & $25.0 \%$ \\
\hline Total & 80 & $100 \%$ \\
\hline \multicolumn{3}{|c|}{} \\
\hline Distribution of patients according to parity \\
\hline Parity & No. of Patients & $\%$ age \\
\hline $1-3$ & 25 & $31.3 \%$ \\
\hline $4-5$ & 28 & $35.0 \%$ \\
\hline$>5$ & 27 & $33.8 \%$ \\
\hline Total & 80 & $100 \%$ \\
\hline
\end{tabular}

\begin{tabular}{|c|c|c|}
\hline \multicolumn{3}{|c|}{ Distribution of patients according to Monthly Income } \\
\hline Monthly Income & No. of Patients & $\%$ age \\
\hline$>10000 \mathrm{RS}$ & 50 & $62.5 \%$ \\
\hline $10000-25000$ & 15 & $18.8 \%$ \\
\hline$>25000$ & 15 & $18.8 \%$ \\
\hline Total & 80 & $100 \%$ \\
\hline
\end{tabular}

\begin{tabular}{|c|c|c|}
\hline \multicolumn{3}{|c|}{ Distribution of patients according to mode of } \\
admission \\
\hline Mode of Admission & No. of Patients & $\%$ age \\
\hline Emergency & 50 & $62.5 \%$ \\
\hline Outdoor & 30 & $37.5 \%$ \\
\hline Total & 80 & $100 \%$ \\
\hline
\end{tabular}

\begin{tabular}{|c|c|c|}
\hline \multicolumn{3}{|c|}{ Distribution of patients according to booking } \\
\hline Antenatal care & No. of Patients & $\%$ age \\
\hline Booked & 30 & $37.5 \%$ \\
\hline Unbooked & 50 & $62.5 \%$ \\
\hline Total & 80 & $100 \%$ \\
\hline
\end{tabular}

\begin{tabular}{|l|c|c|}
\hline \multicolumn{3}{|c|}{ Distribution of patients according to mode of delivery } \\
\hline Mode of delivery & No. of Patients & $\%$ age \\
\hline Spontaneous vaginal delivery & 37 & $46.3 \%$ \\
\hline Elective L.S.C.S & 18 & $22.5 \%$ \\
\hline Emergency L.S.C.S & 25 & $31.3 \%$ \\
\hline Total & 80 & $100.0 \%$ \\
\hline
\end{tabular}

\begin{tabular}{|l|c|c|}
\hline \multicolumn{3}{|c|}{ Risk Factors Associated with preterm labour } \\
\hline Risk Factors & No. of Patients & $\%$ age \\
\hline Bacterial Vaginosis & 20 & $25 \%$ \\
\hline Chorioamnionitis & 10 & $12.5 \%$ \\
\hline Previous H/O preterm birth & 10 & $12.5 \%$ \\
\hline H/O PPROM & 8 & $10 \%$ \\
\hline $\begin{array}{l}\text { H/O Previous C/S } \\
\text { and impending scar } \\
\text { dehiscence }\end{array}$ & 11 & $13.5 \%$ \\
\hline $\begin{array}{l}\text { H/O Ante partum } \\
\text { Hemorrhage }\end{array}$ & 5 & $6.5 \%$ \\
\hline $\begin{array}{l}\text { Pregnancy induced } \\
\text { Hypertension }\end{array}$ & 5 & $6.5 \%$ \\
\hline $\begin{array}{l}\text { Pregnancy with fibroid } \\
\text { uterus }\end{array}$ & 2 & $2.5 \%$ \\
\hline FGR with oligohydramnios & 6 & $7.5 \%$ \\
\hline Pre- Term Breech & 3 & $3.75 \%$ \\
\hline Total & 80 & $100 \%$ \\
\hline
\end{tabular}

\section{DISCUSSION}

Preterm birth is a major cause of perinatal mortality and morbidity in the developed world and accounts for $8-10 \%$ of all birth ${ }^{1}$, whether due to preterm labour or preterm prelabour rupture of the membranes spontaneous preterm birth accounts for $60-75 \%$ of preterm deliveries. ${ }^{2}$

In this study, we have focused at various aspects about the process of preterm birth. The majority of the patients, i.e. 30 patients (37. $5 \%$ ) belong 
to age group between 18-25 years. While 30 patients (37. 5\%) belonged to $26-35$ years and 20 patients (25\%) belong to age group more than 35yrs. In high income countries the increase in preterm delivery is linked to pregnancy among the older women and increase number of multiple pregnancies as consequence of use of fertility drugs. ${ }^{3}$ Maternal demographic variables associated with premature birth include low socio-economic status, literacy level and maternal age..$^{4,5}$

Socioeconomic factor is another important risk factor for preterm labour. It truly is observed that 50 patients (62. 5\%) belonged to low socioeconomic group having monthly income $<10,000$ / month. 15 patients (18.5\%) belonged to group having monthly income between 10-25 thousands and 15 patients (18.5\%) having monthly income $>25000$. It means the prevalence of preterm labour was more in low socio-economic group that is comparable to the results of Meis and colleagues. ${ }^{6}$

There is a good correlation of prematurity with low body mass females as depicted in our study. this finding is proved in multiple trials. ${ }^{7}$ Nutritional status, cigarette smoking, alcoholism and poverty all are contributing factors. ${ }^{8}$

Antenatal booking is very important in prevention of preterm labour. During antenatal period if the risk factors are evaluated properly and proper management is done, the risk of preterm labour can be reduced. In our Study 50 patients (62.5\%) were unbooked and 30 patients were booked. Studies from several developing countries have found the "no ANC visit" is a significant risk factor for pre term birth. ${ }^{9-10}$

Normal vaginal $\mathrm{pH}$ is acidic and is maintained by lactobacilli. The reduced $\mathrm{Ph}$ is a barrier against infections. Bacterial vaginosis is notorious for making a breech in this barrier. In this study, infection was a major risk factor for preterm birth. In 20 patients (25\%) bacterial vaginosis was the cause of preterm labour. These results are compareable to the results of Glantz who reported the bacterial vaginosis as a cause of preterm labour in $40 \%$ cases. ${ }^{11}$ Chorioamnionitis was present in $10(12.5 \%)$ patients. Antibiotics appear to be of benefits in reducing maternal morbidity. Several clinical trails found a reduction in chorioamnionitis with antibiotic treatment. ${ }^{12,13}$

In this study, 14 patients (17. 5\%) had previous pre-term birth and seven patients (11.3\%) experienced history of PPROM. According to Mercer BM \& colleges, after one premature birth, there is an increased risk in the next pregnancy around $20 \%$ and after two, the risk increases to $35-40 \%$. Smoking cessation alone lowers the risk of preterm birth significantly (OR $0.84,95 \% \mathrm{Cl}$ $0.72-0.98){ }^{14}$

$\mathrm{H} / \mathrm{O}$ antepartum haemorrhage and pregnancy induced hypertension was present in five patients (6. $1 \%)$. Our study results were comparable to the Bevely and co. ${ }^{15}$

To enlist and evaluate the conditions in different set ups it is necessary to make some clinical trials at larger level. Also in different set ups the causative factors of preterm labour may be different. As we come across number of patients who are not related to poverty, illiteracy and low weight, there are number of other factors that should be considered like recurrence after one or two episode is very high may be some familial tendency. The identification and diagnosis of preterm labour is also very essential because number of patients usually present with threatened preterm labour or false pains and they may be wrongly labeled as patients of preterm labour.

This study is an effort to find out the aetiological factors associated with premature labour and to find out some remedies against this particular problem related to fetal out come.

\section{CONCLUSIONS}

Some risk factors like previous preterm birth, placental abnormalities, and preterm breech cannot be modified but preventive efforts should be directed towards modifying working conditions during current pregnancy, taking adequate diet, good antenatal care and appropriate 
management of infections and medical disorders. Copyright@ 15 July, 2017.

\section{REFERENCES}

1. Andrews W W, Goldenberg RL, Hath J C, Preterm labor: emerging role of genital tract infections [Review]. Infect Agents Dis 1995; 4: 196-21.

2. Meis $P \mathrm{~J}$, Ernest $\mathrm{J} \mathrm{M}$, Moore $\mathrm{M} \mathrm{L}$. Causes of low birth weight births in public and private patients. Am J. Obstet Gynecol 1987; 156: 1165-1168.

3. "Born too soon," The Global Action Report for Preterm Birth, MoD, PMNCH, Save the Children, WHO, New York, NY, USA, 2012.

4. L.K. Smith, E. S. Draper, B. N. Manktelow, J.S. Dorling, and D. J. Field, "Socioeconomic inequalities in very preterm bith rate," Archives of Disease in Chlidhood: Fetal and Neonatal, Vol. 92, no. 1, pp. F11-F14, 2007. View at Publisher./ View at Google Scholar View at scopus.

5. K.M. Brett, D.S. Strogatz, and D. A. Savitz "Employment's, job strain's, and preterm delivery among women in North Carolina" American Journal of Public Health, Vol. 87, no.2, pp. 199-204, 1997. View at Google Scholar View at Scopus.

6. Meis PJ, Michielutte R, Peters TJ et al. Factors associated with preterm birth in Cardiff, Wales. II. Indicated and spontaneous preterm birth. Am J Obstet Gynecol 1995; 173:597-602.

7. Han Z, Mulla S, Beyene J, Liao G, McDonald SD (2011) Maternal underweight and the risk of preterm birth and low birth weight: a systematic review and metaanalyses. Int J Epidemiol 40: 65-101.
8. Taylor-Robinson D, Agarwal U, Yoxall B, Diggle PJ, Platt $M J$, et al. (2011) Quantifying the impact of deprivation on preterm births: A retrospective cohort study. PLoS ONE 6: e23163.

9. Olusanya B, Ofovwe G: Predictors of preterm births and low birthweight in an inner-city hospital in SubSaharan Africa. Matern Child Health J. 2010, 14: 978986. 10.1007/s10995-009-0528-4.

10. Abrams E, Milner DA, Kwiek J, Mwapasa V, Kamwendo DD, Zeng D, Tadesse E, Lema VM, Molyneux ME, Rogerson SJ, Meshnick SR: Risk factors and mechanisms of preterm delivery in Malawi. Am J Reprod Immunol. 2004, 52 (2): 174-183. 10.1111/j.16000897.2004.00186.x.

11. Glantz JC. Screening and treatment of bacterial vaginosis during pregnancy: a model for determining benefit. Am J Perinatol 1997; 14:487-90.

12. Ernest $J$ M, Givner L B. A prospective randomized placebo-control trial of penicillin in preterm premature rupture of membranes. Am $\mathrm{J}$ Obstet Gynecol 1994; 170: 516-521.

13. Mercer B, Miodovnik M, Thurnau G et al. The NICHDMFMU network: a multi center randomized mass trial of antibiotic versus placebo therapy after preterm premature rupture of the membranes [Abstract]. Am J obstet Gynecol 1996; 174:304.

14. Flood K, Malone FD. Prevention of preterm birth. Seminars Fetal Neonat Med. 2012; 17:58e-e63.

15. BeverlyA, Van Der Pool: Preterm labour: diagnosis and treatment Problem - Oriented Diagnosis. American Family Physician. 1998; 57: 1-10.

\section{AUTHORSHIP AND CONTRIBUTION DECLARATION}

\begin{tabular}{|c|l|l|l|}
\hline Sr. \# & \multicolumn{1}{|c|}{ Author-s Full Name } & \multicolumn{1}{|c|}{ Contribution to the paper } & Author=s Signature \\
\hline 1 & Dr. Tasneem Azher & Main Author \\
2 & Dr. Iram Aslam & Help in data collection \\
3 & Dr. Saadia Bano & Help in data collection \\
4 & Dr. Uzma Shahzad & Help in writing paper & \\
\hline
\end{tabular}

